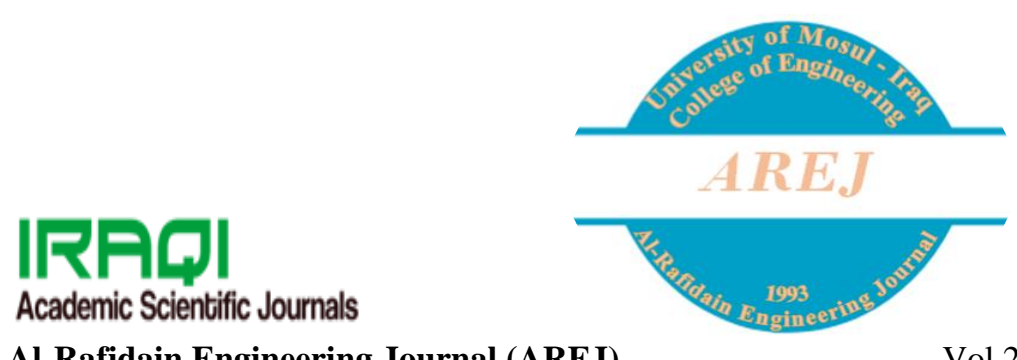

Al-Rafidain Engineering Journal (AREJ)

Vol.26, No.2, October 2021, pp.104-117

\title{
Parking Study at University of Mosul Main Campus
}

\author{
Mohammed Y. Taha \\ mohammedtaha@uomosul.edu.iq
}

Hadeel H. Ali

hh499324@gmail.com

Civil Engineering Department, Collage of Engineering, University of Mosul

Received: 1/12/2020

Accepted: 2/4/2021

\begin{abstract}
During the last years, the Main Campus of Mosul University's growth has meant increased traffic volumes (vehicles and pedestrians flows) on its streets, with longer wait times at the campus gates, and parking problems. The main objective of this work is to describing, measuring and valuing the current condition of parking supply and demand, and recommending the most suitable solutions to parking problems according to the university needs for the future 10 years. The study area is divided into 21 zones. Field surveys include: parking survey, questionnaire survey, and traffic movements survey were conducted to achieve the study objectives. The results show that the largest percentage of faculty members and staff use their vehicles as a motorist, especially males with more than $64 \%$ for faculty and $55 \%$ for staff. The dominant mode of travel for the female faculty members and staff is passengers (Auto and transit) with $60.25 \%$ and $82.1 \%$ respectively There are over 4181 available parking spaces distributed among the study area zones. Additional parking spaces will be provided where possible and a combination of parking structures and surface lots must be resized and located to meet the parking demand for the year 2030.
\end{abstract}

\section{Keywords:}

University of Mosul; Parking Supply; Parking Demand; Campus; Traffic Movements; Parking Survey; Questionnaire Survey; Travel Mode.

This is an open access article under the CC BY 4.0 license (http://creativecommons.org/licenses/by/4.0/). https://rengj.mosuljournals.com

\section{INTRODUCTION}

Parking is one of the important topics in urban transportation planning and traffic management. This is true too for the university campus[1]. Parking facilities and strategies were also importance in traffic engineering. Some researchers described the campuses as small cities [2,3]. However, they have their own physical characteristics that are different from cities or towns [4]. The nature of the traffic and parking characteristics on the university are the reflection of civilization and modernity for this university and pride for its community and motivation for the continuation of the process of scientific and cultural progress [5].Universities with a large population of commuters require more transportation infrastructure including pedestrian ways, bike lanes, parking facilities, etc. [6].

A parking facility is generally defined as "Any building, structure, land, right of way, equipment's or facility used or useful in connection with the construction, enlargement, development, maintenance or operation of any area or building for off-street parking of motor vehicles"[7]. The traffic and parking regulations are for the benefit of the campus community to provide the following: protection of life and property, optimum use of campus roads and parking areas, and continuous flow of traffic [1,2]. If parking facilities are not adequate to accommodate the vehicles causing congestion then it will led more people to park their vehicles along roadside having various problems like delay in time to reach college, pollution (health issues) within campus,etc.[4].

Parking management refers to various policies and programs that result in more efficient use of parking resources. The objective of the Campus Traffic and Parking Management Policy is to ensure that traffic movement and parking by campus users is regulated in a safe and legal manner, for the benefit of the whole campus 
community[8]. Parking management reduces the amount of land required for parking facilities, reduces vehicle use, and increases affordability. This, in turn, tends to reduce vehicle ownership and use, and so reduce parking demand[9]. Current parking planning practices are inefficient, resulting in economically excessive parking supply, increased private car traffic, and more dispersed destinations, contributing to various economic, social and environmental problems. There are many reasons to use management strategies that result in more efficient use of parking resources, in order to address parking problems without expanding supply[10].

A parking area performance indicators are the outcomes of the demand-supply interaction. Congestion at a parking lot occurs when the demand exceeds the supply[11]. Most universities are constantly challenged by the parking congestion problem[12]. On the other hand, because most of the campus users have their own fixed class or work schedule, the parking demand is relatively inelastic. However, the demand can still be managed by a combination of parking price and by providing alternative modes of transportation [13]. Various researches and theories have been developed to determine the supply and demand of parking facilities. There are also many theories about the recommendation and solution of the parking problem. One way to reduce the parking demand is controlling system and regulates charging policy[14]. The mention of efficiency and limited resources for growing demands is useful and supports the reality found on any campus. There is a growing need for access to the campus, which requires active and progressive management of the transportation and parking resources to accommodate the campus' needs today and in the future. It is the mission of campus authority to manage parking resources in a manner that supports campus activities and enhances life in the university community[15].

The University of Mosul is one of Iraq's most considerable academic, scientific, educations, cultural and social center, that contribute and support the society with the professional, technical, and administrative staff in all fields of life. It was established in 1967 with four colleges and a population of around 3000. Currently, the university consists of 24 colleges and a number of scientific, practical, technical, service, health and development centers. The area of the University is estimated about 3 square kilometers distributed over three areas ( Main Campus, Second Campus, and Medicine College) in Mosul City with a population of more than 55 thousand. The University provides advanced programs for higher education in various disciplines at all levels under high standards aimed at presenting more qualified graduates who contribute to the development of society economically and socially.

Many studies, unpublished research, small projects and works are curried out to solve temporary traffic and parking problems within the campus resulting from different traffic cause , emergency conditions, or needs. In 1989 a broad and integrated study in the titled "recommended traffic and parking program for University of Moul Main Campus" was conducted with objective of enhancing traffic operation and to relieve parking problems. This program was developed to reflect the university requirements to meet the predicted traffic and parking needs for the campus in the year 2000 [16]. Many of the paragraphs of this program have not been implemented for a number of reasons, and it cannot currently be implemented due to traffic, construction, and demographic trends and improvements in the study area.

\section{STUDY PROBLEMS}

The University of Mosul Main Campus (UOMMC) is a vital and active university that combines teaching, researching, and servicing to benefit of Mosul city and other nearby cities. It is a focus of traffic generators and draws significant quantities of traffic from widespread areas, both from Mosul and the surrounding cities. The number of vehicles and pedestrian movements on and through the main campus have increased. And as there are no visible changes in the roadway and parking system and network that would result in a reduction of service levels, creating problems of uncomfortable, inconvenient, and unsafe traffic and parking conditions. The private car has had more impact on university campus because most of campus community use their private car. Then the campus obviously faces serious parking problems. Also, there are no sufficient traffic and parking policy and regulation according to trip destination of the campus community. Beside that:

1. Growing university populations created a variety of problems with traffic and parking, leading to the significant students enrolling with a corresponding increase in car ownership and the number of the campus travel trips. The predicted growth of the campus population would only lead to more problems.

2. Due to new infrastructure establishments on the main campus and lack of specific or 
designated parking spaces, campus community persons start parking on the sides of the streets or illegal parking. This creates severe traffic congestion leading to unacceptable and irregular traffic flow for vehicles and pedestrians.

3. Due to the security enforcements at the campus gates, the traffic flow and movements are suffering the congestion and safety problems, which long queues on the streets near the campus gates.

4. A lot of vehicles, not owned by the university community, run through the campus every day, which further loads on the campus traffic and parking demand.

\section{STUDY OBJECTIVE}

The main objective of this study is to describe, analyze and evaluate the existing parking characteristics of UOMMC through extensive fieldwork. The study intended to estimate the nature and quality of the current and future parking supply and demand for each campus zone. Then the study seeks to assess the next 10 years parking conditions and develop suitable solutions for parking problems through to the UOMMC policy, development, community aspirations and present recommendations to improve parking supply in the study area.

\section{STUDY AREA}

The study area (UOMMC) is located in Nineveh governorate, Mosul City within the geographical coordinates: latitude of $(36: 22: 23$ to $36: 23: 38)$ North, and longitudes of $(43: 07: 00$ to 43:10:00) East. The study area is divided into 21 zones with identify boundaries according to the main campus streets or zone topography, as shown in Figure 1.

Through academic year 2019-2020, there are more than 51 thousand persons represent the UOMMC community, that classified into four groups:students, faculty members, staff, and other regular users of Mosul University( daily visitors, contracted, temporary workers, vendors, and any employee of an official or government agency located inside the campus) from the total University number of about 56 thousand persons. The area of the UOMMC is estimated at $2 \mathrm{Km}^{2}$.

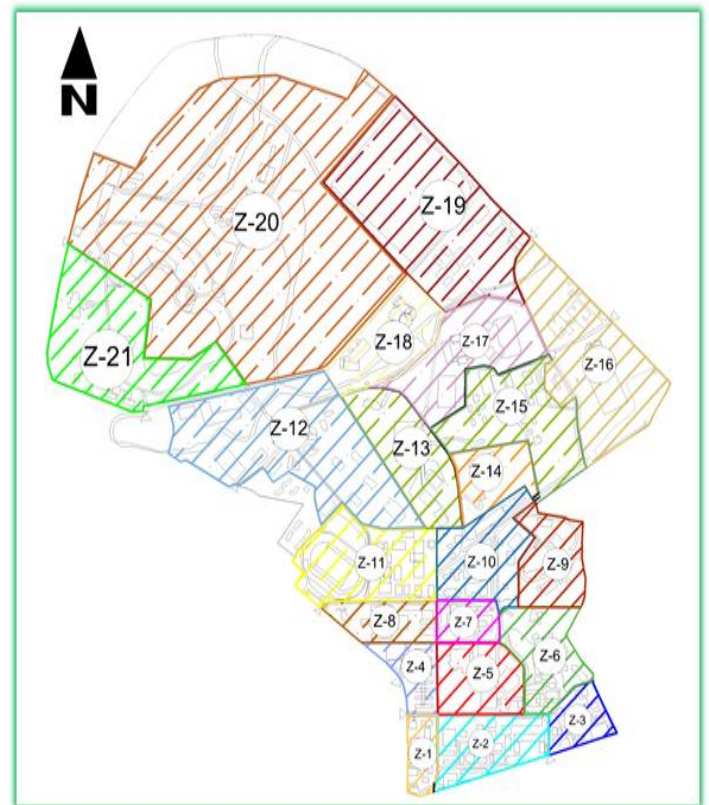

Figure 1. Locations of Zones at Study Area of University of Mosul Main Campus.

Currently as shown in Figure 2 , seven campus gates are using for entering and exiting vehicles and pedestrians, distributed as follows: Gate No.1, 2 and 3 on Street No.1 (Al-Thghafa Street), used for entry and exit of pedestrians only, Gate No.4 on Street No.2 (Al-Manassa Street), while Gate No.5 and 6 set on Street No.3(Al-Hadba Street), and finally Gate No.7 on Street No.4(Al-Qusour Street), these four gates (No.4 to 7) are used to enter and exit vehicles and pedestrians.

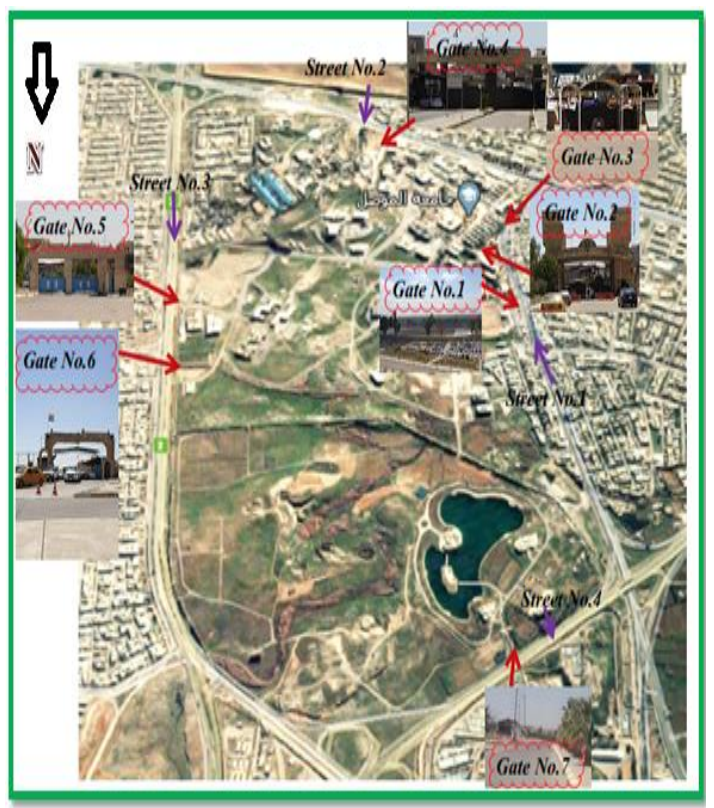

Figure 2. University of Mosul Main Campus Gates. 


\section{DATA COLLECTION}

The information like maps, pictures, natural and social information that belong to the study area were collected with other general data include campus population, car ownership, land use, and policies. The data collection also includes a review of available data and documents at the relevant university departments as the study required. Field surveys include: parking survey, questionnaire survey, and traffic movements survey are intended to provide all the required information according to the goals of this study.

Also study assembly data about location, accessibility, available facilities, and the requirements of the study area with the present and future land use and property data. Monday, Tuesday, and Wednesday were chosen as typical workdays for conducting these surveys from October 7, 2019, to February 11, 2020( between 7:00 a.m. and 7:00 p.m.).

Study of parking facilities are very complex process as it involves numerous activities depending on execution of each activity in accordance with parking specifications and proper survey[17]. The parking phenomenon is usually based on the law of supply and demand. Parking survey includes parking supply (the number of parking spaces available), demand (the number of parking spaces request during peak periods), others parking characteristics ( location, type, turnover, utilization, duration), and parking problems(congestion, conflicts, enforcement, etc.) in each zone of the study area. A parking survey, comprised of inventory and patrol surveys, was carried out to determine the parking characteristics and parking needs by comparing the parking demand with the parking supply at each zone of the study area. In an inventory survey, information of all parking facilities are collected about the type, capacity, location, operating and physical features, and regulations.

In a patrol survey, parking characteristics (accumulation, duration, turnover, and walking distance) are conducted at each on and off-street parking facilities manually for all vehicles parked in each zone of the main campus hourly using the method of periodic monitoring of the video camera. Video provides a permanent record of the study period that may be used for further review of the study data when needed. A parking area at peak hours acts differently than that on off-peak hours, but evaluation of any parking area should be reactive to how parking spaces operate at different periods, for all users. So, the analysis of a parking area must be seeking to balance the functions and needs across all hours of the workday.
A questionnaire survey was a considerable element of the data collection of this work. The questionnaire forms were distributed at random to the campus community in each zone of the main campus, based on the appropriate sample size of each population group. Sample size must depend upon the errors in the data collection process and in the subsequent trip prediction process, where approximate estimates of travel requirements are necessary. As stated by Traffic Engineering Studies ITE Manual[11], The following equation is used to find the necessary sample size:

$$
\mathbf{n}=(\mathbf{S} * \mathbf{K} / \mathbf{E})^{2}
$$

Where $\mathrm{n}$ is the minimum sample size, $\mathrm{K}$ is the constant based on the desired confidence level $(\mathrm{K}=1.96$ for $95 \%$ confidences level), $\mathrm{S}$ is the estimated sample standard deviation or coefficient of variation ( $\mathrm{S} \approx 10-30 \%)$, and $\mathrm{E}$ is the permitted error (in this work $\mathrm{E}=1 \%$ ). For questionnaire survey, the study decided to use $\mathrm{S}=20 \%$ then $\mathrm{n}=$ 1537. Yamane (1967) provides a simplified formula to calculate sample sizes as [18]:

$$
\mathrm{n}=\mathrm{N} /\left(\mathbf{1}+\mathrm{Ne}^{2}\right)
$$

Where $\mathrm{n}$ is the sample size, $\mathrm{N}$ is the population size, and $\mathrm{e}$ is the level of precision. For campus population $\mathrm{N}=50000$ and $\mathrm{e}=2.5 \%$ for $95 \%$ confidences level, then $\mathrm{n}=$ 1550 , which adopted by the study.

The questionnaire form was designed with direct and general of eight questions with multi choices and four questions with short answers as shown in Appendix A. These answers according to the campus community groups gave indications and data such as: Parker destination; distribution of arrival trips to the campus in Mosul city; type of parker vehicle and class (having campus permit or badge to enter the campus); mode of travel; daily entering and exiting campus gate; the preferable campus gate for entering and exiting; and parker suggestions and remarks.

The traffic movements survey was made to collect data about the number and movement of vehicles and pedestrians at selected points within the area of each gate at the main campus are conducted for periods of 12 hours ( 7:00 a.m. to 7:00 p.m.) of a normal weekday using digital camera imaging techniques from a vantage point. The number of entering and leaving vehicles and pedestrians to and from the campus at each gate were recorded.

\section{DATA ANALYSIS}

Upon completion of the field surveys, the collected data were combined and arranged with the data of the questionnaire survey in order to analyze and classified it and then summarized the results. With notice that $75 \%$ of the entering 
vehicles and pedestrians that affiliates to other universities and not affiliated to the campus community were excluded because they are now temporarily present on campus.

\subsection{Growth Factor}

The estimation of parking demand is a very complex subject because the demand is affected by many variables than simple statistics suggest [11] . The analysis of future parking demand need to the forecasting of the campus population and car ownership for the next 10 years.

As shown in Figure 3, UOMMC consists of around 3800 (8\%) faculty members and 4275 $(9 \%)$ staff, and the total number of undergraduate students is around $39750(76.5 \%)$, while the total number of postgraduate students is around 1250 $(2.5 \%)$ persons. The average daily number of other users is around $2000(4 \%)$ persons. Table 1 summarizes the existing distribution of UOMMC population groups in each zone.

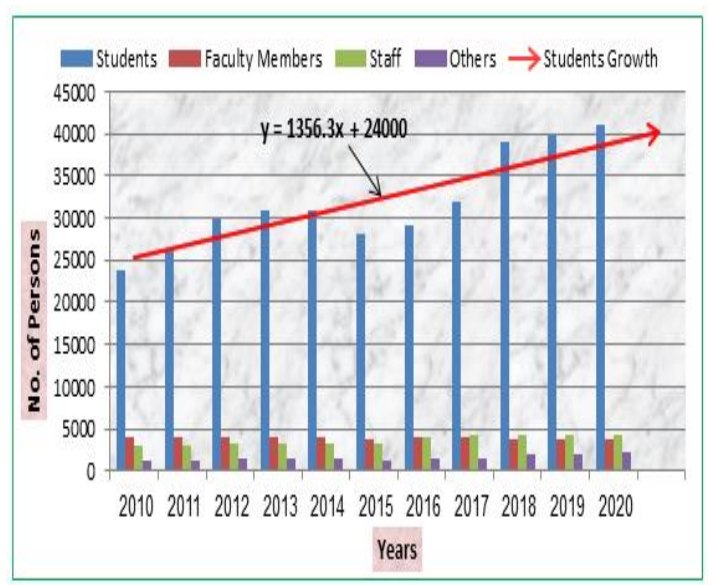

Figure 3. Numbers of Main Campus Community Groups During the Years of 2010 to 2020 .

The total predicted number of campus students group was treated as being the basis of the order for the predicted numbers of other campus community groups with following sequent[16]:

- Forecast students number as a function of time. Which represents the policy of the Higher Education Ministry about the annual students admission plan.

- Estimate the number of faculty members as a function of students number.

- Estimate the number of staff as a function of students and faculty members number.

- Estimate the number of others group as a function of students, faculty members, and staff number.
Based on the general policy setup by the University administration, the recent rate of faculty members to the students should be 1:10 for scientific departments and 1:15 for other departments. While the rate of staff number to the faculty members plus student numbers is $1: 10$.where the number of the other users' group represents the average daily number that be about $4 \%$ of total number of students, faculty members, and staff.

The study recommended a linear equation of the yearly growth rate using the Least Squares Method to the past 10 years trend of the students' numbers, as shown in Figure 3. According to this linear equation, the predicted number of students in 2030 is 51126 persons with a yearly growth factor of $2.305 \%$, which is very close to the yearly growth factor of $2.3 \%$ set by the estimates and expectations of the United Nations Development Program and data in World Bank Report 2020[19] for population growth in Iraq. The study decided to applied this growth rate of $2.3 \%$ to estimate the future parking demand and traffic movements.

Table 1. Distribution of Main Campus Population Groups in Each Zone.

\begin{tabular}{|c|c|c|c|c|c|}
\hline $\begin{array}{l}\text { Zone } \\
\text { No. }\end{array}$ & $\begin{array}{l}\text { Faculty } \\
\text { Members }\end{array}$ & Staff & Students & $\begin{array}{l}\text { Other } \\
\text { Users }\end{array}$ & Total \\
\hline 1 & 128 & 66 & 860 & 61 & 1115 \\
\hline 2 & 385 & 143 & 1968 & 117 & 2613 \\
\hline 3 & 149 & 84 & 791 & 95 & 1119 \\
\hline 4 & 18 & 286 & 0 & 53 & 357 \\
\hline 5 & 22 & 197 & $\mathbf{0}$ & 181 & 400 \\
\hline 6 & 240 & 158 & 1511 & 74 & 1983 \\
\hline 7 & 344 & 131 & 4431 & 114 & 5020 \\
\hline 8 & 123 & 572 & 916 & 202 & 1813 \\
\hline 9 & 292 & 164 & 5096 & 124 & 5676 \\
\hline 10 & 722 & 388 & 6294 & 117 & 7521 \\
\hline 11 & 54 & 81 & 1219 & 85 & 1439 \\
\hline 12 & 271 & 764 & 3427 & 154 & 4616 \\
\hline 13 & 222 & 165 & 5341 & 75 & 5803 \\
\hline 14 & $\mathbf{0}$ & 48 & $\mathbf{0}$ & 43 & 91 \\
\hline 15 & 83 & 87 & 457 & 63 & 690 \\
\hline 16 & 87 & 181 & 886 & 104 & 1258 \\
\hline 17 & 151 & 179 & 2408 & 42 & 2780 \\
\hline 18 & 88 & 118 & 1466 & 44 & 1716 \\
\hline 19 & 238 & 277 & 1614 & 98 & 2227 \\
\hline 20 & 92 & 86 & 769 & 67 & 1014 \\
\hline 21 & 87 & 93 & 1544 & 91 & 1815 \\
\hline Total & 3796 & 4268 & 40998 & 2004 & 51066 \\
\hline
\end{tabular}




\subsection{Questionnaire Form}

The research was able to achieve the appropriate and required sample size of the questionnaire forms that reflects the percentage of each campus population group after the distribution of 5300 forms. These forms ( $60 \%$ given to male and $40 \%$ to females), distributed as 500, 500, 4000, 100, and 200 forms for faculty members, staff, undergraduate students, postgraduate students, and other users group respectively. The aim of the study is to obtain sample size at least of 1550 complete and correct forms and distributed according to the campus community groups percentages. The total number of returned forms, filled completely and correctly, is 2614 forms. The response of the campus community to fill the forms is about $49.3 \%$, distributed as $63.4 \%$ (317 forms), $55.6 \%$ (278 forms), $44.8 \%$ (1793 forms), $81.0 \%$ (81 forms), and $71.5 \%$ (143 forms) for faculty members, staff, undergraduate students, postgraduate students, and other users group respectively. For the results that required achieved the required sample size with normal and real distribution of the campus population, only 1700 forms were selected randomly and used. These selected forms divided as $136,153,1300,34$, and 68 forms for faculty members, staff, undergraduate students, postgraduate students, and other users group respectively.

\section{RESULTS AND DISCUSSION}

After the analysis of the gathering data the following results were recorded:

\subsection{Car Ownership}

The Traffic Administration Department, which is responsible for managing and controlling traffic inside the campus, grants two types of entry badges for vehicles to campus: First, the yearly badges for private vehicles owned by faculty members, staff, postgraduate students, and employees of an official or government agency located inside the campus. Second, monthly or temporary badges for public transit ( taxi car, minibus, bus) used by the campus community. The university enforces strict rules that prohibit students from entering their cars to the campus; therefore, public transport and walking are considered as their most viable methods of getting to their classrooms.

The car ownership percentage for each faculty member and staff group was calculated as the ratio of the number of the permit vehicles of each group that duly registered with the Followup Department to the total number for each group. While the percentage of car ownership for students and other users groups considered as the average car ownership percentage for Mosul city population according to the same gender and age in 2019. The current number of vehicles having to permit yearly badges for the academic year 20182019 was 4369 vehicles for campus community only, distributed as 2218, 1386, 394, and 371 vehicles for faculty members, staff, students, and other users group respectively, While the number of vehicles having to permit temporary badges was 862 vehicles. The percentages of car ownership for the campus community groups during the last 10 years, the current year 2020, and the future year 2030 are given in Figure 4.

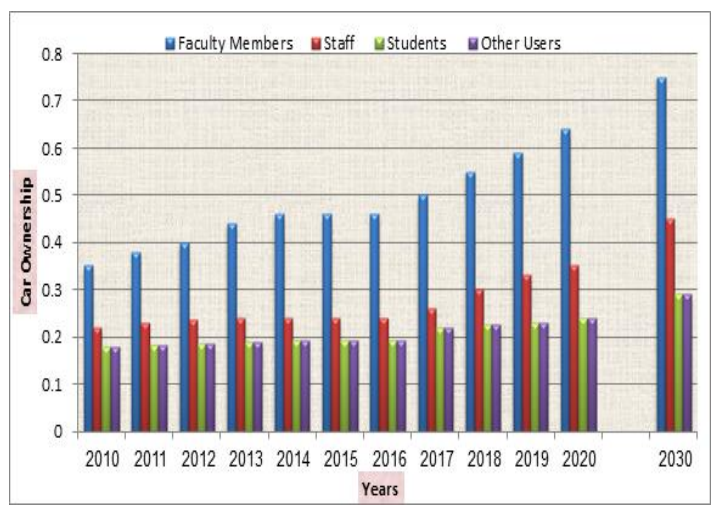

Figure 4. Car Ownership Percentage of Main Campus Community Groups During the Years of 2010 to 2020 , and predicted for 2030 .

\subsection{Arrival and Enter Trips}

With respect to the UOMMC location, the city of Mosul was divided into four zones as shown in Figure 5. The questionnaire survey results show that $11.90 \%, 37.10 \%, 29.33 \%$, and $21.67 \%$ of total arrival trips to the campus are coming from North Zone, East Zone, South Zone, and West Zone respectively.

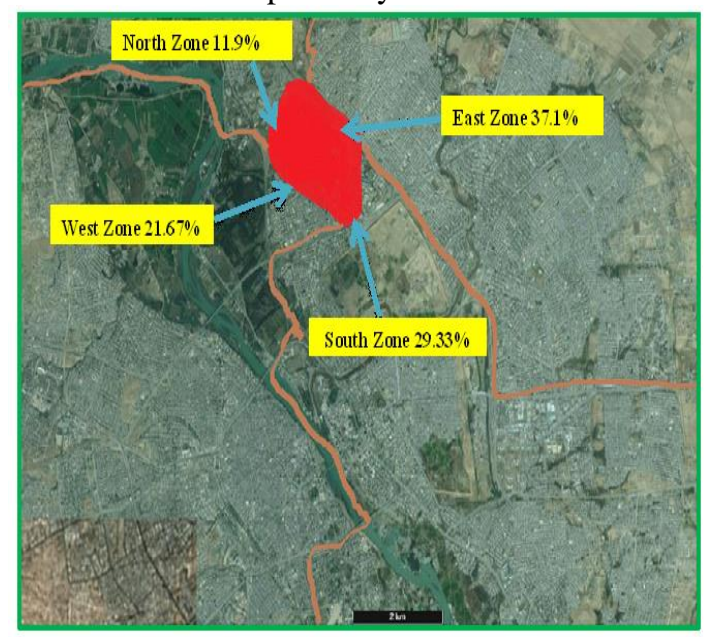

Figure 5. The Percentage of Travel Origin Arrived to University of Mosul Main Campus. 
Based on the questionnaire survey analysis, the total trips arrived at UOMMC are classified as $38.6 \%$ arrived as personal auto trips ( $23.45 \%$ as motorists and $15.15 \%$ as passengers), $59.95 \%$ arrived as public transit passengers $(18.2 \%$ as taxi passengers, $23.1 \%$ as mini-bus passengers, and $18.65 \%$ as bus passengers), and $1.45 \%$ arrived walking. While the total trips entering to UOMMC at all gates are classified as $20.45 \%$ enter as personal auto trips $(10.15 \%$ as motorists and $10.0 \%$ as passengers), $28.55 \%$ enter as public transit passengers ( $8.1 \%$ as taxi passengers, $5.35 \%$ as mini-bus passengers, and $15.1 \%$ as bus passengers), and $51.3 \%$ enter walking. Figure 6 illustrated these results.

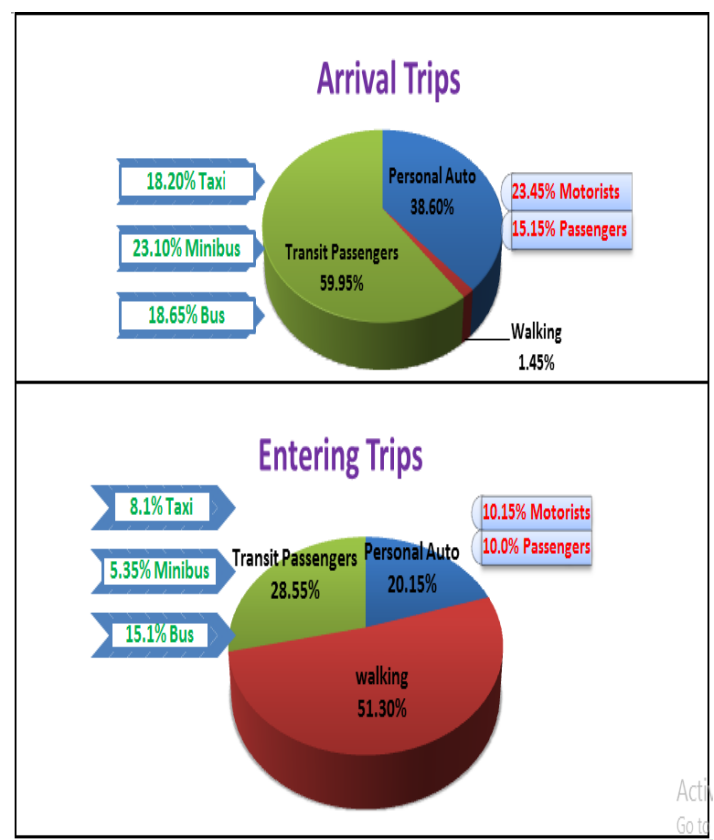

Figure 6. Distribution of Arrival and Entering Trips to University of Mosul Main Campus According to the Mode of Travel.

The distribution of arriving and entering travel trips to the UOMMC for the campus population groups according to trip maker gender are present in Tables 2 and 3 respectively. In these tables, the mode of travel is divided as a motorist, passenger ( auto- or transit passenger), and walking. Where the total trips arrived at the campus are distributed as $75.10 \%$ for passenger mode, $23.45 \%$ for motorist mode, and only $1.45 \%$ for walking mode. While, the total trips entering the campus are distributed as $51.3 \%$ for walking, $38.55 \%$ for passenger mode, and $10.15 \%$ for motorist mode.

Generally, the largest percentage of faculty members and staff use their vehicles as a motorist, especially males with more than $64 \%$ for faculty and $55 \%$ for staff. The dominant mode of travel for the female faculty members and staff is passengers (Auto and transit) with $60.25 \%$ and $82.1 \%$ respectively. While, walking is the mode most used by students to enter the university by up to $63 \%$ ( $83 \%$ of total male students and $34 \%$ for female students), but the means of the passenger (auto and public transit) is the most hired mode to their trips from the origin point to the campus by more than $79 \%$ (66\% of total male students and $97.5 \%$ for female students).

Table 2. Distribution of Travel Mode of Arriving Trips to the Campus According to Trip Maker Occupation and Gender Based on the Questionnaire Survey.

\begin{tabular}{|c|c|c|c|c|c|c|c|c|c|c|}
\hline \multirow{3}{*}{.lode of trarel } & \multicolumn{10}{|c|}{ Person trips $\%$ (out of 1700 respondents) } \\
\hline & \multicolumn{2}{|c|}{ Facultr (8\%) } & \multicolumn{2}{|c|}{ Staffis $(9 \%)$} & \multicolumn{2}{|c|}{ Students $(99 \%)$} & \multicolumn{2}{|c|}{ Other users $(4 \%)$} & \multicolumn{2}{|c|}{ Total } \\
\hline & Ilale & Female & Male & Female & Whale & Female & Male & Female & Wale & Female \\
\hline .lotorist & 39,00 & 15,35 & 32.50 & 7.25 & 18,55 & 0.35 & 10,70 & 3.25 & 21.15 & 230 \\
\hline Autopassenger & 10,90 & 13,35 & 9,10 & 20.80 & 14,00 & 21.00 & 13,00 & 15,75 & $13: 20$ & 20.15 \\
\hline Transit & 9,35 & 11.30 & 13.75 & 14,55 & 25.25 & 19,50 & 37,15 & 19,00 & 23.40 & 18,35 \\
\hline Walling & 0.75 & 0.00 & 1.65 & 0.40 & 1,30 & 0.25 & 0,53 & 0.00 & 1.25 & 0.20 \\
\hline All modes & 60.00 & 40,00 & 57,00 & 43.00 & 59,00 & 41.00 & 62.00 & 38,00 & 39,00 & 41.00 \\
\hline
\end{tabular}

Table 3 . Distribution of Travel Mode of Entering Trips to the Campus According to Trip Maker Occupation and Gender Based on the Questionnaire Survey.

\begin{tabular}{|c|c|c|c|c|c|c|c|c|c|c|}
\hline \multirow{3}{*}{.lode of trarel } & \multicolumn{10}{|c|}{ Person trips $\%$ (out of 1700 respondents) } \\
\hline & \multicolumn{2}{|c|}{ Facultry (8\%) } & \multicolumn{2}{|c|}{ Staffls $(9 \%)$} & \multicolumn{2}{|c|}{ Students $(79 \%)$} & \multicolumn{2}{|c|}{ Other users $(4 \%)$} & \multicolumn{2}{|c|}{ Iotal } \\
\hline & Whale & Female & Nale & Female & Whale & Female & Wale & Female & Whale & Female \\
\hline .lotorist & 38.25 & 15.35 & 31.50 & 6.60 & 1.10 & 0.30 & 9.00 & 3.25 & 7.25 & 2.90 \\
\hline Auto-passenger & 10.50 & 12.65 & 8.70 & 20.50 & 3,30 & 12.65 & 11.25 & 14.15 & 4.70 & 13.40 \\
\hline Transit & 8.25 & 10.65 & 12.75 & 14.55 & 5.40 & 13.75 & 36.15 & 18.45 & 7.35 & 13.10 \\
\hline Wallking & 3.00 & 1.35 & 4.05 & 1.35 & 49.20 & 14,30 & 5.60 & 2.15 & 39,70 & 11.60 \\
\hline All modes & 60.00 & 40.00 & 57,00 & 43.00 & 59,00 & 41.00 & 62.00 & 38.00 & 59,00 & 41.00 \\
\hline
\end{tabular}

Parking is an attribute in the trip destination and mode choice decision making process. The considerable variance in the using percentages of the campus community, especially students group, of the different modes of travel for arrival and enter trips shown in Figure 6 or between Tables 2 and 3 , were reverts to the policy of the campus administration to prevent the largest number of students and visitors to enter the campus with their vehicles led to either stopping their vehicles outside the campus, along the streets near the campus gates or using public transportation, then entering through the campus gates as pedestrians. 


\subsection{Traffic Movements:}

During a typical workday from 7:00 a.m. to 7:00 p.m., the total number of vehicles and pedestrians entering the UOMMC is equal to 8886 vehicles $(96.8 \%$ passenger cars and $3.2 \%$ heavy vehicles) and 22191 persons. The hourly variation of the traffic movements for vehicles and pedestrians are shown in Figures 7 and 8 respectively. The numbers of the vehicles and persons that enter, leave, or still inside the main campus are shown in these two figures. The accumulation number represents the cumulative differences between the entering and exiting numbers of vehicles or pedestrians for each hour. The peak load of entering vehicles of 2768 occurs at 8:00- 9:00 a.m., and exiting vehicles of 2058 at 2:00-3:00 p.m., while the maximum accumulation of 4667 vehicles at 1:00-2:00 p.m. The maximum number of entering pedestrians of 4405 persons occurs at 8:00- 9:00 a.m., and exiting pedestrians of 4456 at 2:00-3:00 p.m., while the maximum accumulation of 10502 persons at 12:00-1:00 p.m.

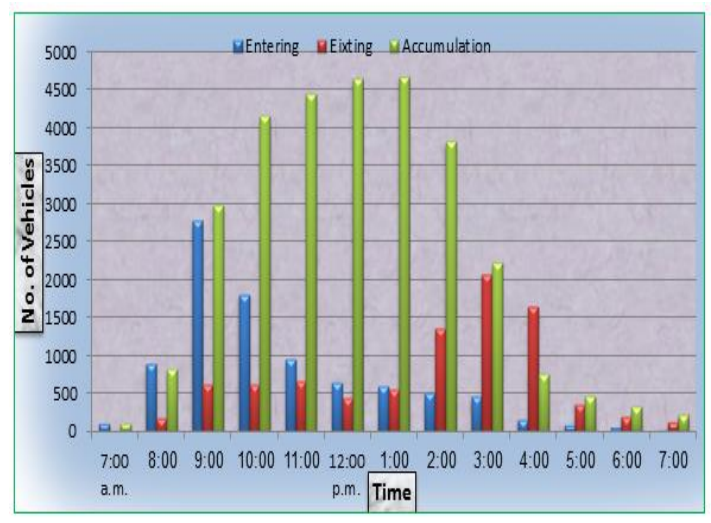

Figure 7. Hourly Variation of Vehicles Movements at Main Campus Gates from 7:00 a.m. to 7:00p.m.

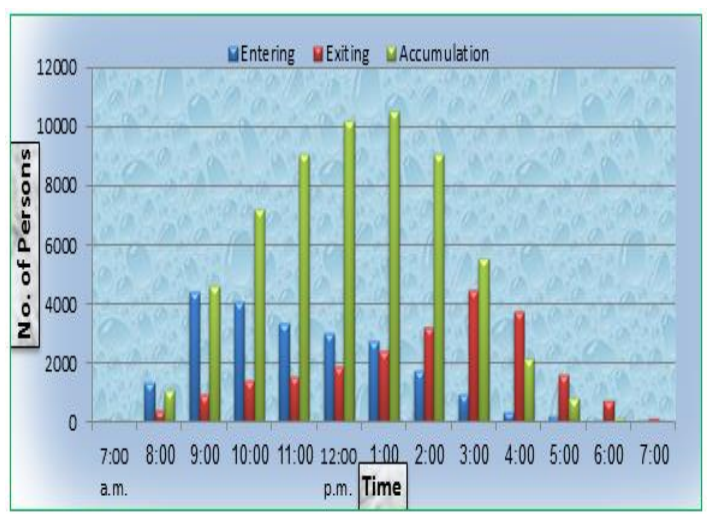

Figure 8. Hourly Variation of Pedestrians Movements at Main Campus Gates from 7:00 a.m. to 7:00 p.m.
Figures 9 and 10 illustrate the distributions of the total number of entering and leaving vehicles and pedestrians at each gate respectively. Gate No. 6 shows a maximum number of 3295 entering vehicles and Gate No.7 of 2738 exiting vehicles, while Gate No.3 shows a maximum number of 4750 entering persons and Gate No.1 of 4445 exiting persons. The questionnaire form review reveals that 24 per cent of respondents were dissatisfied with their current entrance gate., while $16 \%$ of them indicated their dissatisfaction with their current exit gate. Most of these respondents demanded and emphasized the necessity to open gates 1 and 2 for vehicle movements.

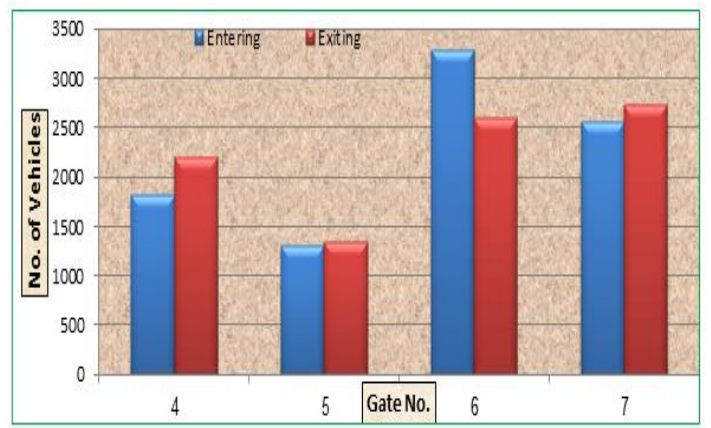

Figure 9. Distributions of the Total Number of Entering and Exiting Vehicles at Each Gate of Main Campus from 7:00 a.m. to 7:00 p.m.

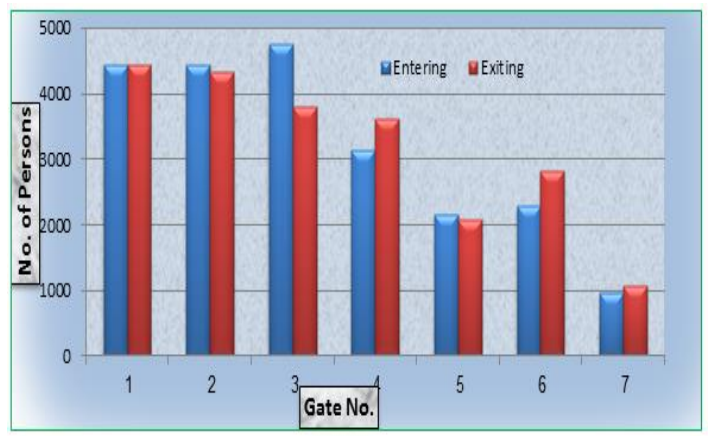

Figure 10.Distributions of the Total Number of Entering and Exiting Pedestrians at Each Gate of Main Campus from 7:00 a.m. to 7:00 p.m.

The peak hour of the entering vehicles of 2917 vehicles from the campus gates occurred between $8: 10$ to $9: 10$ a.m. with maximum numbers of 5 minutes entering vehicles of 307 vehicles at 8:30 to 8:35 a.m. as shown in Figure 11. While the peak hour of the leaving vehicles of 2219 vehicles occurred between 2:20 to 3:20 p.m. with maximum numbers of 5 minutes leaving vehicles of 218 vehicles from 2:40 to $2: 45$ p.m. as shown in Figure 12. 
The entering pedestrian's peak hour of 4877 persons from the campus gates occurred between $8: 15$ to $9: 15$ a.m. with a maximum number of 15 minutes entering pedestrians of 1362 persons from $8: 15$ to $8: 30$ a.m. While the exiting pedestrian's peak hour of 4521 persons occurred between $2: 15$ to $3: 15$ p.m. with a maximum number of 15 minutes exiting pedestrians of 1176 persons from 3:30 to 3:45 p.m.

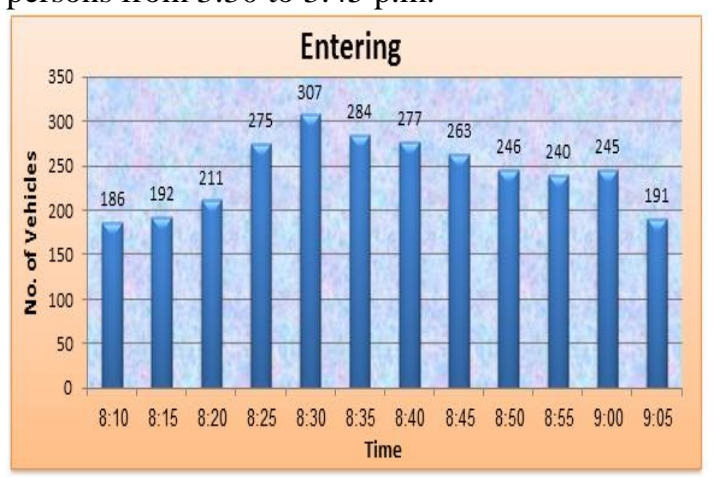

Figure 11. Peak Hour Distribution of the Entering Vehicles to the Main Campus.

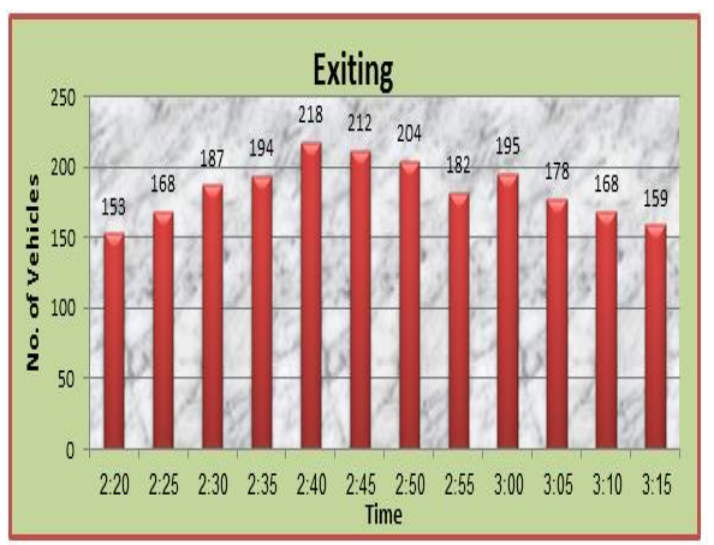

Figure 12. Peak Hour Distribution of the Exiting Vehicles from the Main Campus.

\subsection{Parking Results}

The following parking results are obtained from the data analysis of the parking and questionnaire surveys:

\subsubsection{Parking supply and demand}

For the next 10 years, the study adopted the UOMMC policy to permit only personal vehicles owned by faculty members, staff, postgraduate students, and employees of an official or government agency located on the campus to get the permission of entering and parked their vehicles inside the campus.

Total parking supply had been measured in terms of hour many vehicles can be parked during the period of interest within the study area[14]:

$$
\mathrm{P}=\left(\sum \mathrm{NT} / \mathrm{D}\right) * \mathrm{~F}
$$

where

$\mathrm{P}=$ parking supply, vehicles

$\mathrm{N}=$ numbers of parking of given type and time restriction

$\mathrm{T}=$ time that $\mathrm{N}$ spaces of given type and time restriction are available during the study period, hours

$\mathrm{D}=$ average parking duration during the steady period hours / vehicles.

$\mathrm{F}=$ insufficiency factor to account for turnover values range from 0.85 to 0.95 and increase as average duration increase.

The parking supply in each zone was calculated as a summation of the existing total number of legal parking spaces available at surface parking lots and permitted curb parking. The total parking spaces available at the study area were 4181 spaces, classified as 2532 spaces at surface parking lots and 1649 spaces at permitted curb parking as shown in Table 4. Also, the current total of legal parking spaces available at surface parking lots or permitted curb parking is presented in this table.

Table 4. Parking Characteristics on Main Campus Zones.

\begin{tabular}{|c|c|c|c|c|c|}
\hline \multirow{2}{*}{ Zone $\mathrm{N}_{0}$. } & \multicolumn{3}{|c|}{ Existing Parking Supply } & \multirow{2}{*}{$\begin{array}{l}\text { Walling } \\
\text { Distance } \\
\text { (meters) }\end{array}$} & \multirow{2}{*}{$\begin{array}{l}\text { Parking } \\
\text { Turnover }\end{array}$} \\
\hline & Off-Street & On-Street & Total & & \\
\hline $\bar{l}$ & 71 & 49 & 120 & 50 & 2.19 \\
\hline 2 & 111 & 95 & 206 & 55 & 1.46 \\
\hline 3 & 38 & 83 & 121 & 45 & 1.21 \\
\hline 4 & 127 & 32 & 159 & 40 & 1.77 \\
\hline 5 & 29 & 56 & 85 & 65 & 1.94 \\
\hline 6 & 181 & 55 & 236 & 55 & 1.60 \\
\hline 7 & 153 & 77 & 230 & 80 & 1.27 \\
\hline 8 & 45 & 155 & 200 & 85 & 1.75 \\
\hline 9 & 258 & 90 & 348 & 105 & 1.45 \\
\hline 10 & 195 & 175 & 370 & 65 & 1.70 \\
\hline Il & 80 & 68 & 148 & 75 & 1.55 \\
\hline 12 & 190 & 145 & 335 & 55 & 1.40 \\
\hline 13 & 148 & 102 & 250 & 70 & 1.52 \\
\hline 14 & 75 & 0 & 75 & 45 & 0.75 \\
\hline 15 & 97 & 58 & 155 & 75 & 0.55 \\
\hline 16 & 120 & 65 & 185 & 55 & 1.67 \\
\hline 17 & 175 & 70 & 245 & 80 & 1.41 \\
\hline 18 & 70 & 63 & 133 & 75 & 1.32 \\
\hline 19 & 158 & 57 & 215 & 60 & 1.98 \\
\hline 20 & 104 & 86 & 190 & 85 & 0.80 \\
\hline 21 & 107 & 68 & 175 & 80 & 1.25 \\
\hline Total & 2532 & 1649 & 4181 & 70 & 1.48 \\
\hline
\end{tabular}


Because of the campaign for the reconstruction and rehabilitation of buildings and damaged areas on the main campus that happen in the time of this study, which led to the transfer of the work of the community of departments, colleges, or offices in these zones to other zones, creating a temporary demand for parking spaces in these zones. Figure 13 represents the total parking load at the main campus from 7:00 a.m. to 7:00 p.m.

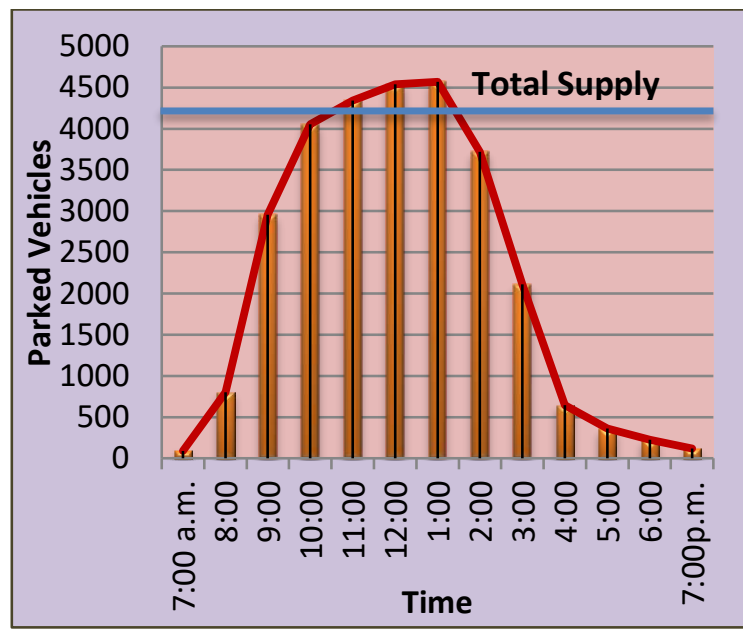

Figure 13. Totat Parking Load at the Main Campus from 7:a.m. to 7:00 p.m.

The normal existing and predicted parking demands in Table 5 were calculated according to the actual normal or predicted location of the departments, colleges, or offices in each zone during the present and future years. The existing and future peak parking demand for each zone excluding the official campus vehicles was determined using the current and predicted number of the permit vehicles according to the current and predicted total number of persons and car ownership of each campus community group in that zone. The calculation was done as follows [16]:

$$
\mathrm{PPD}_{\mathrm{i}}=\mathrm{PPDF} \times \mathrm{TPD}_{\mathrm{i}}
$$

Where:

PPD $\mathrm{i}$ : Peak Parking Demand for Zone i.

PPDF : Peak Parking Demand Factor $=$ Peak Hour Permit Vehicles/ Total Permit Vehicles $=0.849$

TPD $_{\mathrm{i}}$ : Total Parked Demand in Zone i. $\mathrm{i}=1,2, \ldots \ldots, 21$.

The surpluses and deficiencies or needs of parking spaces in each zone were computed throughout the comparison between the peak parking demand and the available supply in that zone. As shown in Table 5, the total current PPD at UOMMC was calculated as 4211 spaces from a TPD of 4955 spaces with a deficiency of 30 spaces, but this value does not mean that there are no parking problems or shortages at all campus locations. The deficiencies of parking spaces in Zone No. 2,9,10, and 12 impose the parkers to park at adjacent zones or parked in an illegal and unsafe manner in these zones. Also, without any additional or new parking spaces, the parking problems and deficiencies will multiply in quantity of each quality.

Table 5. The Existing and Predicted Peak Hour Parking Condition at Each Zone on Main Campus.

\begin{tabular}{|c|c|c|c|c|c|c|}
\hline \multirow[b]{2}{*}{$\begin{array}{l}\text { Zone } \\
\text { No. }\end{array}$} & \multirow[b]{2}{*}{$\begin{array}{c}\text { Parking } \\
\text { Supply }\end{array}$} & \multicolumn{2}{|c|}{ Existing (2019-2020) } & \multicolumn{2}{|c|}{ Future (2030) } & \multirow[b]{2}{*}{ Indications } \\
\hline & & $\begin{array}{c}\text { Peak } \\
\text { Parking } \\
\text { Demand } \\
\end{array}$ & \begin{tabular}{||c|} 
PeakHour \\
Parking \\
Condition \\
\end{tabular} & $\begin{array}{c}\text { Peak } \\
\text { Parking } \\
\text { Demand } \\
\end{array}$ & $\begin{array}{c}\text { Peak Hour } \\
\text { Parking } \\
\text { Condition } \\
\end{array}$ & \\
\hline \multirow{2}{*}{1} & 120 & 134 & -14 & 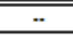 & $=$ & \multirow{7}{*}{ (-) Deficiency } \\
\hline & 120 & 101 & +19 & 135 & -15 & \\
\hline 2 & 206 & 288 & .82 & 378 & .172 & \\
\hline \multirow{2}{*}{3} & 121 & 99 & +22 & .. & .. & \\
\hline & 121 & 116 & +5 & 139 & -18 & \\
\hline 4 & 159 & 140 & +19 & 194 & -35 & \\
\hline ; & 85 & 71 & +14 & $\ldots$ & .. & \\
\hline 5 & 85 & 84 & +1 & 119 & .34 & \multirow{24}{*}{$\begin{array}{l}\text { Noramal } \\
\text { Situation }\end{array}$} \\
\hline 6 & 216 & 178 & +38 & .. & .. & \\
\hline & 236 & 211 & +25 & 276 & .40 & \\
\hline 7 & 230 & 335 & -105 & 422 & .192 & \\
\hline \multirow{2}{*}{8} & 70 & 56 & +14 &.- &. & \\
\hline & 200 & 262 & .62 & 351 & -151 & \\
\hline 9 & 348 & 336 & +12 & 420 & .72 & \\
\hline 10 & 370 & 651 & -281 & 734 & -364 & \\
\hline 11 & 148 & 96 & +52 & 138 & +10 & \\
\hline \multirow{2}{*}{12} & 335 & 420 & .85 &. &. & \\
\hline & 335 & 284 & +51 & 369 & -34 & \\
\hline 13 & 250 & 261 & -11 & 370 & .120 & \\
\hline 14 & 75 & 30 & +45 & 50 & +25 & \\
\hline \multirow{2}{*}{15} & 51 & 25 & +26 &. & .. & \\
\hline & 155 & 96 & +59 & 121 & +34 & \\
\hline 16 & 185 & 136 & +49 & 197 & .12 & \\
\hline 17 & 245 & 193 & +52 & 287 & -42 & \\
\hline 18 & 133 & 116 & +17 & 192 & -59 & \\
\hline \multirow{2}{*}{19} & 185 & 244 & -29 &. &.. & \\
\hline & 215 & 211 & +4 & 289 & .74 & \\
\hline \multirow{2}{*}{20} & 171 & 44 & +127 &. &. & \\
\hline & 190 & 125 & +65 & 175 & +15 & \\
\hline 21 & 175 & 139 & +36 & 192 & .17 & \\
\hline Total & 4181 & 4211 & .30 & 5548 & $-1367 / 2$ & \\
\hline
\end{tabular}

The total future PPD at UOMMC in the year 2030 was estimated as 5548 spaces with a deficiency of 1367 spaces. Increasing parking supply by constructing new parking facilities is an easy solution, if space and budget are both available [11]. A survey of campus gates locations indicate that many students or campus visitors, up to 2000 persons, frequently park their vehicles on- or off streets near to these gates, resulting in traffic and parking problems at these locations. 


\subsubsection{Parking Duration}

The length of time of each vehicle was parked on campus parking spaces was recorded as parking duration. Average parking duration is computed as [14]:

$$
\mathrm{D}=\sum(\mathrm{Nx} * \mathrm{X} * \mathrm{I}) / \mathrm{NT}
$$

where

$\mathrm{D}=$ average parking duration, hour/vehicles

$\mathrm{Nx}=$ number of vehicles parked for $\mathrm{x}$ intervals

$\mathrm{X}=$ number of intervals parked

$\mathrm{I}=$ length of the observation interval, hours

$\mathrm{NT}=$ total number of parked vehicles observed

The average parking duration for all campus community groups is 4 hours and 9 minutes classified as shown in Table 6. All parked vehicles with duration less than 5 minutes are excluded.

Table 6. Parking Duration at Main Campus.

\begin{tabular}{|c|c|c|}
\hline $\begin{array}{c}\text { Parking } \\
\text { Duration } \\
\text { (Hours) }\end{array}$ & $\begin{array}{c}\text { Average } \\
\text { Parking } \\
\text { Duration } \\
\text { (Hours) }\end{array}$ & $\begin{array}{c}\text { \% of Total } \\
\text { Parkers }\end{array}$ \\
\hline Less than 1 & $\mathbf{0 . 7 0}$ & 11.40 \\
\hline $1-2$ & 1.80 & 10.85 \\
\hline $2-3$ & 2.67 & 13.05 \\
\hline $3-4$ & 3.75 & 14.33 \\
\hline $4-5$ & 4.45 & 15.10 \\
\hline $5-6$ & 5.70 & 20.67 \\
\hline More than 6 & 7.65 & 14.60 \\
\hline
\end{tabular}

\subsubsection{Walking Distance}

A good indicator of parker comfort and convenience is the walking distance from where the vehicle is parked to the final destination. The average walking distance of the parkers at each campus zone is ranging from 40 to 105 meters as presented in Table 4. The average walking distance of the total campus parkers was about 70 meters, which can classify the parking condition as a good level of comfort and convenience. According to the analysis of questionnaire forms, More than $85 \%$ of total motorists confirmed the satisfaction of their current parking space locations concerning their final destination and walking distance.

\subsubsection{Parking Turnover}

The evaluation of the efficiency of any parking space may be made by parking turnover value that equal to the total number of parked vehicles divided by total parking supply for specified parking locations and survey duration of
12 hours. The turnover was calculated as follows [14]:

$$
\mathrm{TR}=\mathrm{NT} / \mathrm{Ps} * \mathrm{Ts}
$$

Where:

$\mathrm{TR}=$ parking turnover rate, $\mathrm{veh} / \mathrm{stall} / \mathrm{hr}$

$\mathrm{NT}=$ total number of parked vehicles observed

Ps $=$ total number of legal parking stall

Ts = duration of the study period, hours

The parking turnover at the campus zones varies between 0.55 to 2.109 , while the parking turnover of total parking on campus equal to 1.48 , Table 4 summarizes all these results. These results indicated that turnovers are not so high, mainly because about $50 \%$ of total parked vehicles have a parking duration of more than four hours.

\section{CONCLUSIONS AND RECOMMENDATIONS}

The growth of campus population, car ownership, and usage increase every year, which has resulted in not only significant traffic problems and congestions but severe parking shortages too. The personal vehicle becomes an important component of a campus transportation system and a preferable mode of travel for the campus community. This because, it offers the best level of comfort and convenience, door-todoor service, and great flexibility in travel planning. Due to the size and distribution of Mosul city areas, with the trip origin and destination points far away from each other, the need to save time used in routine travel to and from UOMMC, and the desire for comfort and avoidance of severe weather conditions, walking as a travel mode is very limited. So that, the authority of UOMMC should encourage the campus community to shift their travel modes from personal vehicles to other types of travel, especially walking. Therefore, a feasible and attractive commuting alternatives are needed to encourage the campus population to walk.

Excluding the locations or zones of parking spaces on campus, the study found a total deficiency of 30 and 1367 spaces to meet the current and future peak parking demand respectively. The highest current parking deficiency of 281 spaces was present in Zone 10 as the most attractive location on campus, this deficiency increased to 364 spaces in the year 2030. The most core campus parking surface lots were effectively full during peak parking demand periods. The existing UOMMC parking ratio was approximately 0.68 spaces per all permitted vehicles and 0.55 spaces per all parked vehicles. 
If this ratio was maintained, UOMMC would need an additional parking supply of 1500 spaces in 2030. Options might include increasing parking capacity in high-demand areas such as near the Zone $7,8,10,13$, or student center, a one-level structure over the current parking lots in these locations are recommended. Moreover, three proper sites of multi-level structures for parking on campus, each with a capacity of not less than 200 spaces, would improve traffic distribution and minimize future parking problems and needs.

The main campus doesn't just need to be buildings and structures that keep users comfortable and provide a workspace, also need to think through how these things are connected, and how to use spaces for interactions and movements, which can support increased productivity, creativity, development, and resolution of the traffic and parking problems.

Therefore, develop strong transit connections among the various locations on campus may be necessary. Adequate transit services on or around campus with convenient facilities at most transit stops, provide access to all places on-campus and, have minimal environmental and visual impacts. Extensive pedestrian network with an enjoyable walking environment connecting to all major campus buildings, campus gates, transit stations, and other popular pedestrian destinations.

The study recommends delegating the authority of the UOMMC to enforce reasonable regulations of traffic, parking facilities, and pedestrian movement zones necessary for the safety, satisfaction, and welfare of the university community.

\section{ACKNOWLEDGEMENTS}

The authors wish to express sincere appreciation to the authority of University of Mosul, Engineering College, and Civil Engineering Department for their continuous support and encouragement for this work. The authors would also like to thank the director and members of the Engineering Affairs Department to provide their assistance. The authors are indebted to the directors, faculty members, staff, and students of the University of Mosul Main Campus for their cooperation with and participation in this work.

\section{REFERENCES}

[1] R. Boob, and A.P.Biswas,"Analysis and Proposal for Construction of Parking Facility at MIT College Campus", International Journal of Civil Engineering and Technology Volume 9, Issue 7, pp. 20-30, July 2018.
[2] S. Ison, and Corinne Mulley," Parking Issues and Policies", Emerald Group Publishing Limited Howard House, Wagon Lane, Bingley, UK, p.442, First edition 2014.

[3] H. M. Alshuwaikhat, and I. Abubakar, "Integrated Approach to Achieving Campus Sustainability: Assessment of the Current Campus Environmental Management Practices", Journal of Cleaner Production, Vol. 16, No. 16, pp. 1777-1785, 2008.

[4] O. Yerli, and Sinem Ozdede, Design Process of a Campus Plan: A Case Study of Duzce University Konuralp Campus", Jou.of Engineering Research and Application, Vol.7, Issue 4, ( Part -1), pp.50-59, April 2017.

[5] R. P. Roess, Elena S. Prassas, William R. McShane ,"Traffic Engineering", $3^{\text {rd }}$ Edition, Pearson Prencite-Hall, United State, 2004.

[6] R. Aldrete-Sanchez, Jeff Shelton, and Dr. Ruey Long Cheu, P.E., " Integrating The Transportation System With A University Campuses Transportation Master Plan : A Case Study", Technical Report 0-6608-2, Texas Transportation Institute, p.138, 2010.

[7] R. Boob, and A.P.Biswas," Analysis for the Need of Parking Management System in Campus of MIT College", International Research Journal of Engineering and Technology (IRJET), Volume 5 Issue 5, pp. 912-921, May-2018.

[8] D. H. Kaplan,and Thomas Clapper, "Traffic Congestion on a University Campus: A Consideration of Unconventional Remedies to Non-traditional Transportation Patterns", Planning of Higher Education Journal, Vol. 36, No. 1, pp.28-39, 2007.

[9] R. Lee, Robert Rees, and Mackenzie Watten , "Smart Growth Parking Requirements Review," ITE Journal (www.ite.org), Vol. 80, No. 12, pp. 34-40, December 2010.

[10] T. Litman,"Parking Management Comprehensive Implementation Guide ", Victoria Transport Policy Institute, p. 80, June 2011.

[11] I. of Transportation Engineers, Anurag Pande, and Brian Wolshon," Traffic Engineering Handbook, Seven Edition, John Wiley \& Sons, Inc., New Jersey, 2016. 
[12] S. Huayan, Lin Wenji, Huang Haijun, "Empirical Study of Parking Problem on University Campus", Journal of Transport. Systems Engineering and Information Tech. Vol. 7, Issue 2, pp.135- 140, April 2007.

[13] R. L. Cheu, et. al.,"Characterizatio of University Parking System ", Final Report, Center for Transportation, Environment, and Community Health, U.S. Department of Transportation, Texas, p. 56, 2018.

[14] S. Norhisham, and N. Ismail, "Case Study on Supply and Demand for University Parking Facilities in College of Engineering, Universiti Tenaga Nasional ", International Conference on Construction and Building Technology, E-36, 2008, pp435-448.

[15] C. State University," Parking and Transportation Master Plan", Kimley-Horn and Associates, Inc., Fort Collins,Colorado, p.127, 2014.

$\underline{\text { Appendix A }}$

Wniversity of Mosul- Engineering College Civil Engineering Department
[16] M. Y. Taha, " Recommended Traffic and Parking Program For University Of Mosul MainCampus", M. Sc. Thesis submitted to The College of Engineering, University of Mosul, 1990.

[17] S. Kumar Singh,"Study of Parking Patterns for Different Parking Facilities", International Journal of Civil and Structural Engineering Research, Vol. 2, Issue 2, pp. 35-39, 2015.

[18] I., Glenn D.," Determining Sample Size", PEOD-6, Program Evaluation and Organizational Development, IFAS,Florida University, PP.1-5, 2003.

[19] World Bank, "World Development Report 2020 Chapters and Data: Population Growth (Annual \%)", World Bank Group, Washington D.C., 2020.

We thank and appreciate your cooperation with us to achieve the smoothness, safety and regularity of traffic and parking on campus

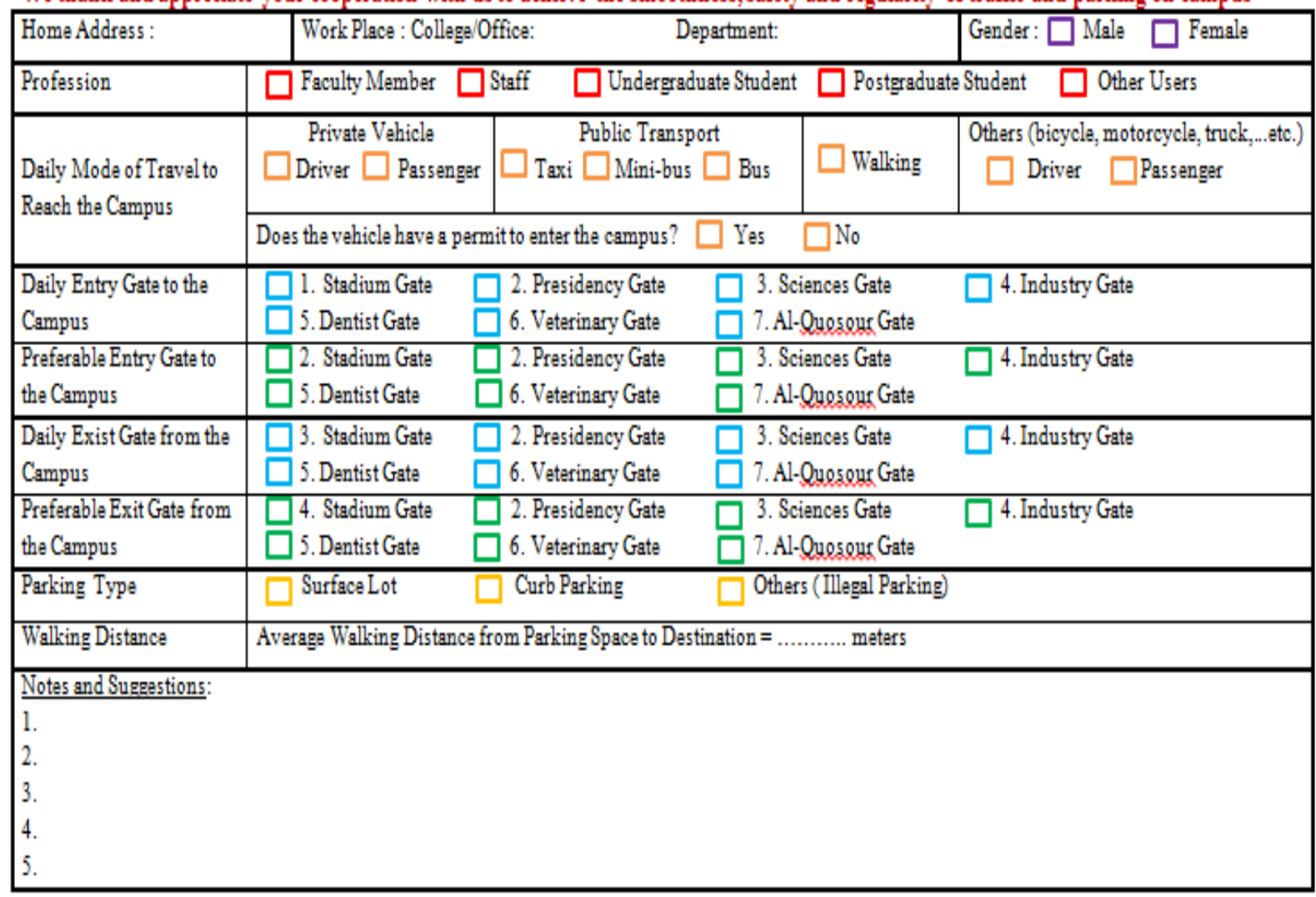

Figure A-1. Study Questionaire Form 


\section{دراسة مواقف المركبات في الحرم الجامعي الرئيسي لجامعة الموصل \\ السيدة هديل حسين علي \\ hh499324@gmail.com \\ محمد ياسين طه \\ mohammedtaha@uomosul.edu.iq \\ جامعة الموصل ـ كلية الهندسة ـ قسم الهندسة المدنية}

خلال السنوات الماضية ، شهر مجتمع الحرم الجامعي الرئبيسي لجامعة الموصل نموا واضحا، ومن نتائج هذا الندو زيادة حجم فئم

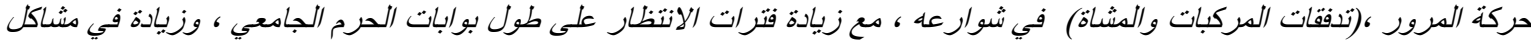

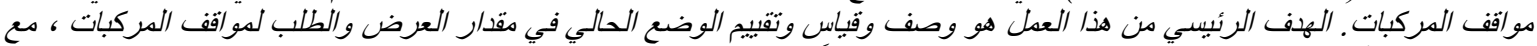

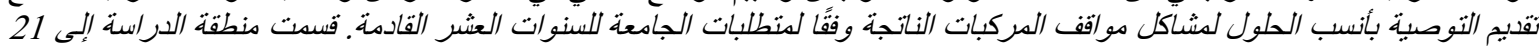

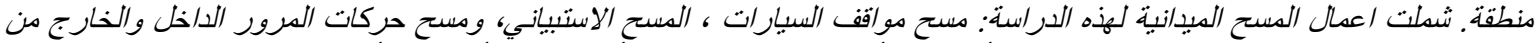

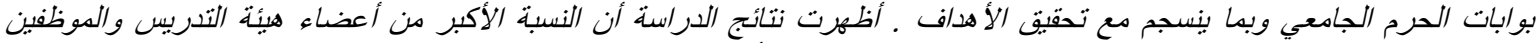

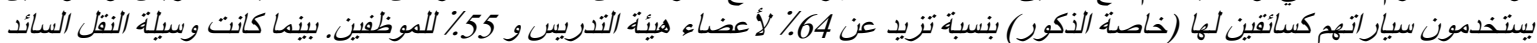

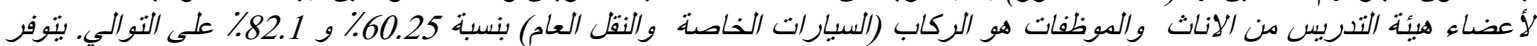

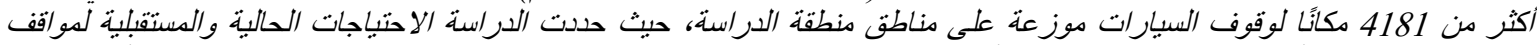

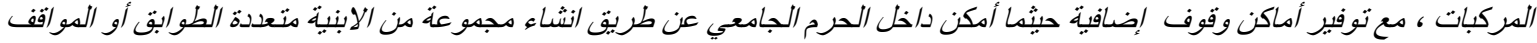

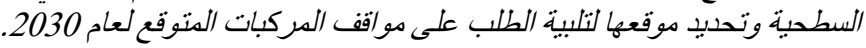

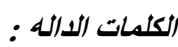

جامعة الموصل،مقد/ر العرض والطلب لمواقف المركبات،الحرم الجامعي،حركات المرور، المسح الاستبياني ،وسبلة النقل. 